\title{
Values, Classical Political Economy, and the Portuguese Empire
}

\section{Citation}

Rotschild, Emma. 2012. Values, classical political economy, and the Portuguese empire. Values and Justice. Special Issue. Journal of Economic Methodology 19(2): 109-119.

\section{Published Version}

doi:10.1080/1350178X.2012.683594

\section{Permanent link}

http://nrs.harvard.edu/urn-3:HUL.InstRepos:10718368

\section{Terms of Use}

This article was downloaded from Harvard University's DASH repository, and is made available under the terms and conditions applicable to Open Access Policy Articles, as set forth at http:// nrs.harvard.edu/urn-3:HUL.InstRepos:dash.current.terms-of-use\#OAP

\section{Share Your Story}

The Harvard community has made this article openly available.

Please share how this access benefits you. Submit a story.

\section{Accessibility}




\section{VALUES, CLASSICAL POLITICAL ECONOMY, AND THE PORTUGUESE EMPIRE ${ }^{\mathrm{i}}$ Emma Rothschild}

The critique of political economy as unfounded, or as founded on false assumptions - on an understanding of human nature which is too simple, or too cold, or too unedifying - is at least as old as Adam Smith's earliest critics. "The heart of flint that has disgraced the beginning of the nineteenth century", the English radical William Godwin wrote in 1820, was the characteristic, in particular, of "as many of us as studied the questions of political economy." Political economy, he wrote in his extended response to Malthus's Essay on Population, is inimical to "all the ramifications of social existence"; it sees the world as a cold and cruel scene, or as "a city under the severe visitation of a pestilence." To read the Wealth of Nations, Godwin said, is to feel "a painful contraction of the heart." ${ }^{1}$ For the French conservative L.G.A. Bonald, in 1802, the "administration of things has been perfected at the expense of the administration of men," and Adam Smith's work was "the bible of this material and materialist doctrine." ${ }^{2}$

These criticisms have endured, in various forms, over the past two centuries. The assertion, at its most general, is a tripartite critique. Political economy, it is suggested, has, in the first place, put forward a false understanding of individual human beings, as uniquely selfinterested and calculating, without virtue or values. It has in the second place, in its criticisms of the state, reduced the capacity of societies to act collectively, in the spirit of solidarity, community, sympathy and other human values. It has in the third place, and most insidiously, had the effect of changing human nature itself; of contributing, over time, to the transformation of society into a materialist wasteland of competitive individuals. ${ }^{3}$

The early criticisms are astonishingly resilient, and they have many intriguing characteristics, including their capacity to appeal to both the historical "left" and the historical

\footnotetext{
${ }^{i}$ Revised version of a paper presented at the University of Coimbra in March 2011.
} 
"right." They are in most respects a travesty of the political economy of the great eighteenthcentury founders of economic thought, including Adam Smith himself. Smith wrote extensively in the Wealth of Nations about the complexity of economic sentiments, and his other great work, the Theory of Moral Sentiments, begins with a celebrated statement of the limits of a narrow view of self-interest: "How selfish soever man may be supposed, there are evidently some principles in his nature, which interest him in the fortune of others, and render their happiness necessary to him, though he derives nothing from it except the pleasure of seeing it." ${ }^{4}$ A.R.J.Turgot, who even more than Smith is the founder of modern laissez-faire economic policy, wrote of the postulate of universal self-interest that "in the sense that this proposition is true, it is childish, and a metaphysical abstraction from which there is no practical result to be drawn, because it is then equivalent to saying that 'man only desires that which he desires.' If [the suggestion is of] a reflective, calculated interest by which man compares himself to others and prefers himself, then it is false that even the most corrupt men behave according to this principle. ${ }^{5}$

This paper is concerned with one theme in the early criticisms of Adam Smith's economic theory, to do with Smith's ideas of empire in general, and of the Portuguese empire in particular. The disputes over Smith's views of empire, Portugal and the English East India Company, I will suggest, can illuminate the setting in which he wrote the Wealth of Nations, the "foundational" difficulties of some of his ideas, and even the enduring difficulties of laissez-faire over very long and transnational distances. I will be concerned with an historical institution (the Portuguese empire in Asia) which was in decline in 1776; with a writer on economic ideas (the poet William Julius Mickle), who is now almost entirely unknown; and with a medium of economic thought (footnotes to the introduction to a translation of Os Lusíadas, the Portuguese epic poem of 1572 about the discovery by Europeans of a sea route to Asia), which is spectacularly unlikely, in the context of modern economic publishing. The paper is an essay, in this sense, in the "'new' 'new' history of economic thought", which seeks to examine economic 
ideas in a capacious context of other contemporary writings and discussions, both "high" (or theoretical), "medium" (or political), and "low" (or popular), and also in the context of economic and political events. It is an effort, in turn, to show that even a historical or historicist history of economic thought can be of interest for large and important questions of economic theory and economic method.

Portugal and Britain were intimate allies, in the years during which Adam Smith was writing the Wealth of Nations. The formal Portuguese empire in Asia was reduced to the settlements of Goa and Macau, and even in naval warfare, Portugal was in Smith's description "a very weak ally. ${ }^{\prime 6}$ But the Portuguese mercantile empire in the South Atlantic and the Indian Ocean was flourishing. Portuguese/Brazilian merchants sent more enslaved Africans across the Atlantic, over the 150 years from 1700 to 1850, than Britain and France combined, and the Atlantic, African and Asian trades were closely connected. ${ }^{7}$ One of the customary routes for English East India Company ships bound for Calcutta and Madras was via Brazil. English ships stopped in Mozambique, en route to India, and the East India Company was itself actively involved in the slave trade from Angola to Sumatra. ${ }^{8}$ English and French ships sold Indian textiles in Luanda, in the Angolan slave trade to Brazil. ${ }^{9}$ Smith's own associates from Scotland were frequent visitors to Lisbon, and to the Portuguese empire. As the brother of Smith's friend William (Johnstone) Pulteney wrote from Lisbon in 1761, where he was posted as a naval officer and living with a family of Scottish merchants, "they savour of the warmth of Jamaica without the deceit... A strange People. Carnavall time. The ruins of Lisbon where everything fills \& Employs the Imagination." 10

Smith was in general a fierce critic of what he described in a letter to a Scottish acquaintance as "the futile and expensive friendship of Portugal." It was a "silly notion," he wrote in the Wealth of Nations, that "England could not subsist without the Portugal trade." The officially sanctioned commerce between the two countries was in his description an outcome of the "sneaking arts of underling tradesmen," "erected into political maxims for the conduct of a 
great empire." But the Portuguese empire was in one respect, for Smith, an encouraging model. For it was an empire, at least in Asia, without the exclusive companies that were Smith's great object of obloquy in the Wealth of Nations. "That such companies are not in general necessary for carrying on the East India trade, is sufficiently demonstrated by the experience of the Portugueze, who enjoyed almost the whole of it for more than a century together without any exclusive company," Smith concluded; the Portuguese empire in Asia had "some faint resemblance to the colonies of America." 12

It was these observations on East India companies, and on the Portuguese model, that inspired one of the earliest extended controversies, in print, over Smith's economic theories. The publication of the Wealth of Nations, in March 1776, was followed by relatively few reviews, in the journals of which Smith "never spoke but with ridicule and detestation." 13 The three early responses on which Smith himself commented were by Thomas Pownall (concerned with American affairs), by "a Gentleman of the name of Douglas" (on national defense), and by "a very diligent, laborious, honest Man of the name of Anderson" (on corn exports); as Smith concluded, in a letter of 1780 to a Danish-Norwegian friend, the "single, and as, I thought a very harmless Sheet of paper, which I happened to Write concerning the death of our late friend $\mathrm{Mr}$ Hume, brought upon me ten times more abuse than the very violent attack I had made upon the whole commercial system of Great Britain. So much for what relates to my Book." ${ }^{14}$

William Julius Mickle was a minor Scottish poet of the conservative enlightenment, and his criticism of Smith, in 1778, was distinctively abusive..$^{15}$ A few days after the publication of the Wealth of Nations, in March 1776, Mickle had published a verse translation of Os Lusíadas, the great epic poem by Luís Vaz de Camões. ${ }^{16} \mathrm{He}$ described the poem, in an extended (158-page) introduction, as of direct interest to contemporary discussions of 'the true spirit of commerce,' and of "that stupendous Commonwealth, the United East India Company." "It is the Epic Poem of the Birth of Commerce. And in a particular manner the Epic Poem of whatever country has the controul and possession of the commerce of India," Mickle wrote. The sixteenth-century epic 
was concerned in particular, in Mickle's account, with the divergent interests whereby "the viceroy or governor always finds two interests, often different from each other, soliciting his attention; the public interest and his own private one;" "this is the one great principle upon which the British East India Company must exist or fall." The subscribers to the poem included East India Company officials, in London and Bengal, and the entire project was inspired, in Mickle's account, by "their desire to see an Epic Poem, particularly their own, in English."17

It was in the second edition of the English Lusiad, published in 1778, that Mickle launched his violent attack on Smith. The first edition had been widely reviewed, and one of the reviews, in the Gentleman's Magazine, contrasted Mickle's history of the Portuguese empire, admiringly, to those in the Abbe Raynal's Philosophical History of the Two Indies, and in "an elaborate work lately published" (the Wealth of Nations.) ${ }^{18}$ Mickle's new introduction was even longer than the first (236 pages), and was divided into eight chapters, of which one, "The Application," is a detailed examination of Smith's arguments about India in the Wealth of Nations. In a subsequent, anonymous work of 1779, with the elaborate title, A Candid Examination of the Reasons for Depriving the East-India Company of its Charter, contained in "The History and Management of the East-India Company, from its Commencement to the Present Time." Together with Strictures on some of the Self-Contradictions and Historical Errors of Dr. Adam Smith, in his Reasons for the Abolition of the said Company, Mickle returned to the critique of Smith, together with copious quotations from his own earlier writings ("an author whom we shall be necessitated frequently to cite"), and a new denunciation of a recent history of the East India Company by the poet James Macpherson (who had himself written of Smith that he was "one of my best friends.") 19

Smith's views of long-distance commerce were summarized by Mickle in four propositions: that "Exclusive Companies are in every respect pernicious;" that the Portuguese commerce with India flourished without monopoly companies; that "under a Free Trade factors would settle in India of their own accord;" and that when forts and garrisons are absolutely 
necessary, it is best that they should be "under the immediate protection of the sovereign." These prospects, Mickle wrote, in an idiom which was later so ubiquitous in the critique of political economy, are no more than "the dreams and dotage of Theory." Smith's "scheme of voluntary, unconnected settlers in India," or of a "free trade with Asia," was absolutely impractical: "no theory can be more weak and visionary than that which supposes that the trade of the East may be carried on in the same safe and easy manner as that of the ports of Europe, where mutual commercial interest is fully understood and established." There "is not one idea of Indian jealousy and hatred of Europeans," and "it is, according to the Doctor, as safe to settle in, and trade with India, as to take a counting-house near London-bridge, or to buy a peck of peas at Covent-Garden." ${ }^{20}$

Mickle's criticism was focused on the uses and misuses of the history of Portugal - or on Smith's propensity for "fixing on the Portuguese as his favourites" - and on Smith's denunciations of the English and Dutch East India companies. Smith was derided, a little surprisingly, for his "abhorrence of commercial pursuits," and in particular for his view of the "'strange absurdity" by which the English East India Company merchants have transformed themselves into sovereigns. The idyll of free and competitive trade between Europe and Asia was for Mickle a fantasy, and Smith's prospect of a more enlightened policy - to "save the poppies and rice of Bengal from an untimely plough" - was the object of heavy irony. Smith's plan of reform, in which the settlements in the East Indies would be "'taken from the exclusive companies to which they at present belong, and put under the immediate protection of the sovereign," would "amputate the limbs, and dislocate the joints of commerce." Smith was even, most surprisingly of all, charged with an unsuspicious confidence in the virtues of government: "the most cordial affection for the kingly power." 21

The "cheerful vigour of commerce can only be uniform and continued, where the merchant is conscious of protection, on his appeal to known laws of supreme authority," Mickle wrote. But the protection of the British government, in India, would be illusory. Mickle 
questioned Smith's presumption that "a free trade, and revenue, is the interest of a sovereign." He also questioned the virtuousness of the sovereign, or at least of the sovereign's subaltern officers in the distant provinces of empire. "The rapacity of distant governors, so strongly exemplified by the Portuguese" was a counter-argument to Smith's proposed reforms. Mickle returned to his theme of multiple interests, from the earlier introduction: "Every governor feels two objects soliciting his attention, objects frequently incompatible, at least not easily to be reconciled - the public, and his own private interest." He turned Smith's criticism of the subaltern clerks of East India Company against him, “only substituting the word King, where he writes Counting House:" "Nothing can be more completely foolish than to expect that the clerks of a great King, at ten thousand miles distance, and consequently almost quite out of sight, should, upon a simple order from their master, give up, at once, doing any sort of business upon their own account, abandon for ever all hopes of making a fortune, of which they have the means in their hands, and content themselves with the moderate salaries which their master allows them."22

There was even a far more general critique of Smith's economic theory, both in the introduction to the Lusiad and in the Candid Examination of 1779. Mickle addressed himself, like so many subsequent critics, to the defense of corporations: "that old monopoly, the institution of corporations, was at one period highly political, and absolutely necessary to support infant commerce." He defended practical experience against "abstract Speculation" and the spirit of "system" ("a strong passion for speculation and theory is the disease of the age.") He described the beneficial consequences of "regulation" for the development of industry. He poured scorn on Smith's confidence that if manufacturers in one branch of industry lose their workshops, "they would immediately turn their capitals and industry into other channels, which would be of equal advantage to their country." He addressed himself, in a 167-line footnote to the "Introduction" to the Lusiad (with two footnotes within the footnote), to the central proposition of all Smith's theory -- that individuals "are much better judges than any statesman 
or lawgiver" of their own interests, or, "our Author's plan, that Government should leave every subject to the course of his own industry." "We flatly deny," Mickle wrote, that "'every individual is continually exerting himself" "for advantage or improvement. There was rather a "stupor and obstinacy," or "a torpor on the general mind of such districts as are ignorant of commerce, which requires to be roused into action by those of superior intelligence."23

Mickle's writings about Smith are works of the moment, full of repetitions and misrepresentations. He was part of a conservative enlightenment, or counter-enlightenment, dedicated to criticizing the deism, irreligion, subversion and prose style of Voltaire, Hume and Smith, in which even Hume's death, in 1776, was the occasion for a new poem: "And Smith, in barbarous dreary prose,/ Shall grunt and croak his praise." ${ }^{24}$ The origins of Mickle's dislike of Smith appear to have been personal as well as political, in that Mickle believed that Smith had advised his former pupil, the Duke of Buccleuch, against becoming the patron of the first edition of the Lusiad. ${ }^{25}$ Mickle's pious disclaimer in the "Advertisement" to A Candid Examination"The Author of the following Pages solemnly disclaims every the most remote Connection with the East-India Company" - was accurate only to the extent that his earlier efforts to achieve a position, or a subscription, had been unsuccessful. ${ }^{26}$

The "Introduction" to the Lusiad is also an early contribution to racial and religious theories of European dominion in India. It was written at a time when the "East," and India in particular, was still described by English and French commentators as the richest region of the world: "all the riches of India," or the "immense overflow of riches, from the East." India was for Mickle "perhaps the most fertile country in the world." It is interesting that one of Mickle's charges against Smith is that the proposed free trade with India "would injure our own manufactures," unable to compete with Indian industries: "silks, muslins, calicoes, embroidery, cottons, toys, and many of the Indian manufactures, would greatly injure those of this country, were a free importation allowed." "A free importation of the woven manufactures of India, which are now under restriction, would greatly injure out own manufacturers," he reiterated in $A$ 
Candid Examination. ${ }^{27}$ The Indian "hatred of foreigners" was in Mickle's account "a jealousy and aversion primarily founded on the most rational and political views." 28 But the introduction to the Lusiad "in its English dress" was at the same time a relatively early statement of the racial generalizations that were so important in the nineteenth-century British empire. ${ }^{29}$

Vasco de Gama's voyage was presented by Mickle as a part of a Portuguese plan for the "universal propagation of Christianity," or a "mortal wound to Mohammedanism;" it was a victory over the "Moors, great masters of the arts of traffic," and in particular over the Arab merchants who were "sole masters of the Ethiopian, Arabian and Indian seas" ("this crafty mercantile people," "like the modern Jews.") ${ }^{30}$ The "wide and stupendous effect" of British dominion was for Mickle a victory, by contrast, over "the abject spirit of Asiatic submission," and "the dispirited and passive Gentoos." His other extended addition to the second edition of the Lusiad, in addition to the attack on Smith, was a 28-page "Enquiry into the Religious Tenets, and Philosophy of the Brahmins." This was a further diatribe, most notable for the echoes of criticisms of Smith in Mickle's view of Hindu philosophy, and of Hindu philosophy in Mickle's view of Smith, in which the "boundless chaos of confusion and contradictions" of the philosophy of the Hindus, in 1778, was transposed, in 1779, into the "mere chaos of confusion" of Adam Smith's and James Macpherson's philosophy of government. ${ }^{31}$

The contrast with Smith's own views of race and empire is striking, once again. One of Mickle's many complaints against the early Portuguese colonists was that they "encouraged the marriage of the Portuguese with the natives:" "the descendants of these marriages people the coasts of the East at this day. They are called Mesticos or Mestizes, are become savages, speak a broken Portuguese, called lingua Franca by the sailors. Many of the black servants brought to Europe are of this race." Adam Smith, in a very different spirit, described Brazil as "a great and powerful colony:" "there are said to be more than six hundred thousand people, either Portugueze or descended from Portugueze, creoles and mulattoes, and a mixed race between 
Portugueze and Brazilians. No one colony in America is supposed to contain so great a number of people of European extraction." ${ }^{32}$

Mickle is for all these reasons an unlikely figure in the history of economic thought. To the extent that he was a writer on economic subjects, he belongs to the history of "low" or "medium" economic thought, and not to the "high" economic theory of which Smith is so widely

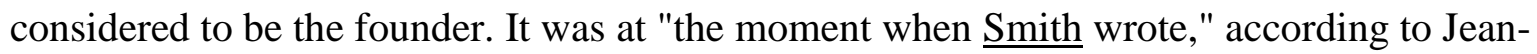
Baptiste Say's early nineteenth-century history, that political economy was distinguished, for the first time, from the science of politics. ${ }^{33}$ Even Smith's earliest critic, Thomas Pownall, wrote a little condescendingly, in 1776, that "I really do think that your book, if corrected on these points, might become... AN INSTITUTE of political oeconomy, such as I could heartily wish... that some understanding Tutor in our Universities would take up, as a basis of lectures on this subject. ${ }^{34}$ Mickle was admired as a poet, and his translation of the Lusiad was far more extensively reviewed than the Wealth of Nations. ${ }^{35}$ But he belonged to an earlier and unscientific epoch in writing on political economy. He was never "respectable" or well-established, in the sense that was so important to Smith; he belonged to the "low enlightenment" of printers, proofcorrectors, reviewers, and seekers of passing patronage. ${ }^{36}$

Mickle's criticism of Smith's views of long-distance commerce is an outline, even so, of two of the most profound difficulties of Smith's system. The first has to do with the security or protection of economic exchange. The idea of security is at the heart of Smith's economic system, and of his economic history of Europe, which turns on "order and good government" and "the liberty of every individual, the sense which he has of his own security": the "equal and impartial administration of justice which renders the rights of the meanest British subject respectable to the greatest, and which, by securing to every man the fruits of his own industry, gives the greatest and most effectual encouragement to every sort of industry." ${ }^{\prime 37}$ There is a world of exchange, industry, and traffic, and a world of the law by which exchanges are protected. This is the conception which corresponds, in Smith's own thought, to the distinction depicted by 
twentieth-century economists, between the market and the state. The market, in Smith's description, is the space of competition, and the state, or the law, is (or should be) the space of equality and impartiality.

The difficult question is about the overseas commerce which was such a dominating theme of Smith's writing. For the impartial and protective state, in Smith's account, is the state, or the system of laws, of a particular country. Overseas and long-distance commerce were dependent, by contrast, on disparate sources of security. They required at least one of four sorts of "order," if they were to be tolerably secure. The first was the order which is provided, in distant societies, by the political institutions of those societies themselves; this was the policy of the English East India Company before the 1760s, derided by Mickle as the "little cunning finesse" of cajoling Indian princes. ${ }^{38}$ The second was the self-protection, or self-regulation, of the East India Company merchant-sovereigns, or the system of oppression which was Smith's great object of denunciation in all his writings on India. The third was the order provided by institutions which transcend the frontiers of existing political societies; or the prospect of an oceanic government, or a world assembly, with which so many eighteenth-century figures, including Smith, were so intrigued. The fourth was the order provided by the sovereigns of the merchants' own society; this was the recourse of empire, in a military and political sense, or, for Mickle, "the spirit of Gothic conquest." 39

Mickle's criticism of Smith, for all its violence, pointed to a serious difficulty in Smith's theory of long-distance commerce, which was that he did not accept any of these four possible orders. He was respectful of the "Mahometan government" of Bengal, without being prepared to confide to it the orderliness of British commerce. He rejected the merchant-sovereigns. He was intrigued by systems of government across frontiers, but concluded in the Wealth of Nations that the possibility of a "general union," even within the British empire, was no more than a "new Utopia." ${ }^{, 40} \mathrm{He}$ was in favour of an expansion of the role of the British sovereign in India - taking the settlements from the exclusive Companies, and putting them "under the immediate protection 
of the sovereign" -- without considering the extent to which this would bring with it all the oppressions of the subaltern officers of the state, and all the ills of empire which he elsewhere denounced.

The second difficulty of Smith's economic system is related, and it has to do with private and public interest. In the twentieth-century distinction between the market and the state, the market is the space of private self-interest, subject to the rules and norms of competition; and the state (or at least the good, protective state) is the space of the public interest, subject to the rules and norms of public service. But these rules and norms are the outcome, in general, of particular societies. They are evanescent, even at home, and invisible when the particular society, or particular friends, are "at ten thousand miles distance, and consequently almost quite out of sight."

Individuals pursue their own self-interest, as Smith showed so devastatingly, by seeking to influence the rules of competition and the regulations of the state. They buy ideas and information about regulation, and the member of parliament who attempted to oppose the private interests of manufacturers would be subjected, in Smith's description, to the "most infamous abuse and detraction", arising from the "insolent outrage of furious and disappointed monopolists." The politically connected merchants and manufacturers had increased in power in England, by 1776, to the point where, "like an overgrown standing army, they have become formidable to the government, and upon many occasions intimidate the legislature." ${ }^{42}$ The servants of the state, over the same period, had pursued their own private interests even in their public offices. The objective of private interest was public influence, and the objective of public service was private advantage.

These were the dilemmas of the Portuguese viceroys in India, and of the East India Company merchant-sovereigns of Smith's and Mickle's own time. The exclusive companies which Smith so disliked were an instance of the indistinctiveness of the private and the public, as the private self-interest of the companies was directed, in England, towards the pursuit of 
political rules, and the public objectives of the legislature were inspired by private interest. The East India Company, in India, was private and public at one and the same time; in the description of a another "low" writer on economic affairs, William Bolts, whose book on the East India Company was one of Smith's sources for the Wealth of Nations, the "monstrous government" of the "Merchant-sovereign and the Sovereign-merchant." ${ }^{43}$

The story of Smith's early critics, and of the contested history of the Portuguese empire, can shed an interesting light, for all these reasons, on the history of Smith's own times, and on his economic thought. It shows the extent to which Smith's economic writings, and the responses of his contemporary critics, were concerned with long-distance, overseas and colonial commerce; and with economic circumstances (like the organization of the Portuguese empire in Asia, or the early constitution of the East India Company, or the superior competitiveness of the Indian textile industry) which were archaic, even in the 1770 s, as well as with the new circumstances (like the organization of a rising empire in America) which are of so much vaster importance in the retrospect of history. ${ }^{44}$

The disputes over William Julius Mickle's criticisms of Smith show that even "low" economic thought can be of interest in understanding the contemporary setting of Smith's theories. These criticisms were echoed, in much more seemly form, in the course of the eventual demise of the East India Company from the 1820s to the 1850s, as Smith's proposed reform - in which the English settlements in India would be "taken from the exclusive companies," and "put under the immediate protection of the sovereign" - was combined with Mickle's own idyll, of a Christian, righteous, and naturally superior empire. ${ }^{45}$

The story of the Portuguese connection provides a glimpse, too, of the world of commerce in which Smith and his acquaintances lived, in the transitional times of 1776. It was a world in which Portugal was a rising as well as a declining power, and in which the informal and often illicit exchanges between Portuguese and British merchants are a brilliant illustration of the almost-public almost-private world that Smith described. William Bolts's own Portuguese 
adventures are a particular case. Bolts was a German-Dutch factor, who was closely connected to the Johnstone family who were William Julius Mickle's patrons. He lived in Lisbon for extended periods, including during the time of Mickle's own visit to Portugal (where Mickle was secretary to George Johnstone, of whom he wrote that "to this Gentleman, in great measure, the appearance of the Lusiad in English is due." $)^{46}$

In March 1776, as the Wealth of Nations and Mickle's translation of the Lusiad were being published in London, William Bolts arrived in Lisbon, on board an English ship, with a mutinous crew, that on arrival in Portuguese waters had changed its name from the Earl of Lincoln to the Joseph and Theresa, and hoisted the colours of the Austrian empire. The ship had both an Austrian and a Turkish passport, and it was reported to have arrived in Lisbon to collect a shipment of Brazilian tobacco for the East Indies, with the backing of Antwerp and Frankfurt merchants; it was bound for Livorno, Madeira, and eventually for the East Indies ("some of the islands... perhaps in the Gulph of Bengal," the British ambassador reported to London.") One of the ambassador's sources was a merchant named Cantofer (of whom the ambssador added that "in general the reverse of what Mr. Cantofer says is true.") It was reported that "the Empress queen has permitted Bolts to provide himself from Her mines;" Bolts himself said that "there is a ship building for him at Trieste." The secretary of state in London wrote that "the information respecting Mr Bolts has been conveyed very confidentially to the East India Company; the ambassador responded that "I cannot help thinking that this Business is of a serious nature, \& deserves the attention of Government." ${ }^{, 47}$

This was the real world of long-distance commerce, in 1776, and it was a world, or an economy, which is very difficult to describe in the familiar language of nations and their interests, or of markets and states. But it is not a world which is entirely unfamiliar, in our own age of sovereign-merchants and merchant-sovereigns. The free exchanges of commerce required good rules, including rules of competition and rules for the security of property, as Smith understood, and they also required good values, or good norms; the disposition of merchants to 
compete by mild and moderate means, and for economic rather than political advantage. The profound difficulty of Smith's system, for his early critics, was that the course of free commerce -- and the celebration of the virtues of self-interest -- had the effect, over time, of reducing respect for rules, and changing the norms of competition. The commercial society was founded on uncommercial values, and its tendency, eventually, was to consume its own foundations. These are some of the difficulties, too, of modern political economy. 
$\underline{\text { Notes }}$

${ }^{1}$ William Godwin, Of Population: an Enquiry concerning the power of increase in the numbers of mankind, being an answer to Mr. Malthus's Essay on that subject (London, 1820), pp. 110, $112,611,620$.

2 L.G.A. de Bonald, Législation primitive considérée dans les derniers temps par les seules lumières de la raison (Paris, 1802), 2 vols., vol. 2, pp. 89-90.

${ }^{3}$ On the early critics of political economy, see Emma Rothschild, The Inner Life of Empires: An Eighteenth-Century History (Princeton, 2011), pp. 149-153.

${ }^{4}$ Adam Smith, The Theory of Moral Sentiments, ed. D.D.Raphael and A.L.Macfie (Oxford, 1976), p. 9.

${ }^{5}$ Letter of early December 1773 from A.R.J. Turgot to M.R.A.N.Condorcet, in Correspondance inédite de Condorcet et de Turgot 1770-1779 (Paris, 1883), ed. Charles Henry (Paris, 1883), pp. 143-44.

${ }^{6}$ Adam Smith, An Inquiry into the Nature and Causes of the Wealth of Nations, ed. R.H.Campbell and A.S.Skinner (Oxford, 1976), p. 549.

${ }^{7}$ The Trans-Atlantic Slave Trade Database, available at http://wilson.library.emory.edu:9090/tast/assessment/estimates.faces

${ }^{8}$ See letters of May 9 1764, November 211764 and February 151765 from the Directors of the East India Company in London to the Company's Council in Calcutta, and letters of September 301765 and March 241766 from the Council in Calcutta to the Directors in London, in Indian Records Series: Fort William-India House Correspondence, gen. ed. T. Raychaudhuri, 21 vols. (Delhi, 1949-1985), vol. 4, pp. 39, 40, 60, 71, 357, 404.

${ }^{9}$ Joseph C. Miller, Way of Death: Merchant Capitalism and the Angolan Slave Trade 1730-1830 (London, 1988), chapters 8, 10, 16 and 17.

${ }^{10}$ Letter of February 181761 from George Johnstone to William Johnstone, Huntington Library, San Marino, CA, Papers of William Pulteney, PU 469 [453]. David Wedderburn, an acquaintance of Smith and the brother of another close friend, stopped in the Cape Verde Islands ("in all my travels I never saw so very horrid a place") on his way to Bombay in 1770 . He provided "some bark, some Salt of Wormwood, \& some Snuff" to the very melancholy Portuguese governor ("upon my asking him, how long he intended to remain here, he answered with a very deep sigh, probably as long as the Count D'Oyeras [the prime minister, Pombal] 
lived"), and was presented with "some hogs, fowls, goats \& vegetables"; he also found twenty German soldiers, who had been shipwrecked on a Dutch East India Company ship, and whom he took with him to Bombay, into the service of the English Company. Letter of May 81770 from David Wedderburn to Janet Erskine, National Archives of Scotland, Papers of the Sinclair family, Earls of Rosslyn, GD164/1698.

${ }^{11}$ Letter of October 141782 to John Sinclair of Ulbster, in Adam Smith, The Correspondence of Adam Smith, 2nd ed., ed. E.C.Mossner and I.S.Ross (Oxford, 1987), p. 262.

${ }^{12}$ Smith, The Wealth of Nations, pp. 493, 549, 633, 635.

${ }^{13}$ Quoted in "Anecdotes tending to throw light on the character and opinions of the late Adam Smith, LLD" (1791), in Adam Smith, Lectures on Rhetoric and Belles Lettres, ed. J.C.Bryce (Oxford, 1983), p. 230.

${ }^{14}$ Letter of October 261780 to Andreas Holt, in Smith, Correspondence, p. 251.

${ }^{15}$ There is a single extended study of Mickle's life and work: Sister Eustace Taylor, William Julius Mickle (1734-1788): A critical study (Washington, DC, 1937).

${ }^{16}$ Luis de Camöens, The Lusiad; or, the Discovery of India. An Epic Poem, transl. William Julius Mickle, $1^{\text {st }}$ edn. (Oxford, 1776). The translation, with its heroic evocation of mercantile, political and scholarly wisdom, and of the glories of the university of Coimbra (in which Camöes learned "an intimacy with the classics, equal to that of a Scaliger, but directed by the taste of a Milton or a Pope") was widely considered to have introduced Portuguese history and literature to an English audience:

"The rocks on every shore/

Resound the dashing of the merchant-oar./

Wise laws are form'd, and constitutions weigh'd./

And the deep-rooted base of Empire laid.../

Coimbra shines Minerva's proud abode/

And... beholds another dear-loved Athens rise."

The Lusiad (1776), pp. clxxxviii, 119.

${ }^{17}$ Mickle, "Introduction," in Camöens, The Lusiad (1776), pp. civ-cvi, cliii.

18 "Much, therefore, is due to the man, who, by wading through the Portuguese and Spanish writers, has shed true light on that wide political field, where a Reynal, and other eminent philosophers, have wandered astray and stumbled." Gentleman's Magazine, vol. 46 (August 1776), 367-369, p. 368.

${ }^{19}$ [William Julius Mickle], A Candid Examination (London, 1779), p. 6; letter of March 251776 from James Macpherson to John Macpherson, Macpherson Papers, British Library, Oriental and India Office Collection, Mss Eur F291/122. 
${ }^{20}$ Mickle, "Introduction," in Luis de Camöens, The Lusiad; or, the Discovery of India. An Epic Poem, transl. William Julius Mickle, 2nd edn. (Oxford, 1778), pp. clxi, clxxv; Mickle, A Candid Examination, pp. 17-18, 26.

${ }^{21}$ Mickle, "Introduction" (1778), pp. clxvii-ix, clxxi, clxxvii, clxxix.

${ }^{22}$ Mickle, "Introduction" (1778), pp. clxxi, clxxxiv, clxxxvi; and see Smith, The Wealth of Nations, p. 638.

${ }^{23}$ Mickle, "Introduction” (1778), pp. clxii, clxxvi-vii, A Candid Examination, pp. [4], 10.

24. "On the Death of David Hume," in The Poetical Works of William Julius Mickle, collated by Thomas Park (London, 1808), p. 144 [mispaginated; 162].

25 "Anecdotes of William Julius Mickle," in William Julius Mickle, Poems, and a Tragedy (London, 1794), pp. xxxvii-xxxix.

${ }^{26}$ Mickle, who was the son of a Scottish clergyman with an unfortunate side venture in brewing, was close to destitution for much of the 1760s and 1770s. His great hope, as he explained to his brother, was to become a clerk in the West Indies, or the purser on East India Company ship. A letter to the Chairman of the East India Company, dated March 1 1776, and asking for a subscription to the Lusiad, was marked "never delivered." Undated letter of [1765] from William Julius Mickle to Charles Mickle, letter of March 11776 from George Johnstone to Mr Harrison, Osborn Mickle Papers, Beinecke Library, Yale University; and see The Rev. John Sim, "The Life of the Author," in The Poetical Works of William Julius Mickle (London: 1806).

${ }^{27}$ Mickle, "Introduction" (1778), pp. xvii, liii, clxxiv, clxxxv, A Candid Examination, p. 24.

${ }^{28}$ A Candid Examination, p. 15.

${ }^{29}$ See C.A.Bayly, The Birth of the Modern World, 1780-1914: Global Connections and Comparisons (Oxford, 2004), and, on early British views of Indians as "aerially predisposed to indolence," Emma Rothschild, "Social Security and Laissez Faire in Eighteenth-Century Political Economy," Population and Development Review, Vol. 21, No. 4 (Dec., 1995), 711-744, pp. 730-731.

30 "When Gama arrived in India, the Moors, great masters of the arts of traffic, were the lords of the eastern seas. They had settlements on every convenient station, from Sofala to China; and though under different governments, were in reality one great commonwealth." Mickle, "Introduction" (1778), pp. xl, li, clvii.

${ }^{31}$ Mickle, "Introduction” (1778), pp. xii-xiii; "Enquiry," in The Lusiad (1778), p. 332, A Candid Examination, p. [4]. 
${ }^{32}$ Mickle, "Introduction" (1778), p. lxxxviii; Smith, The Wealth of Nations, p. 569.

33. Jean-Baptiste Say, "Discours préliminaire," in Jean-Baptiste Say, Traité d'Economie Politique, ou simple exposition de la manière dont se forment, se distribuent, et se consomment les richesses (Paris, 1803), p. i.

${ }^{34}$ Thomas Pownall, A Letter from Governor Pownall to Adam Smith, LLD, FRS (London, 1776), p. 48

${ }^{35}$ The two works were published at almost exactly the same time. There was an extended review of the Wealth of Nations in the Monthly Review (vols. 54 and 55, 299-308, 455-469, 16-26), in addition to shorter notices in the Scots Magazine (vol. 38, 205-206) and the London Magazine (vol. 45, 321-322). The Lusiad was reviewed in the London Review (vol. 3, 19-25, 90-102), and again in 1778 (vol. 7, 1-10, with comments on Mickle's criticism of Smith), the Monthly Review (vols. 54 and 55, 249-260, 369-383, 5-16, and, in 1778, vol. 59, p. 311), the Critical Review (vol. 41, 15-26 and in 1778, vol. 46, pp. 62-64), the Lady's Magazine (vol. 7, 129-130), and the London Magazine (vol. 45, 210-211), as well as the Gentleman's Magazine (vol. 46, 367-369 and vol. 48, 427-428), with comments both in 1776 and 1778 on Mickle's criticism of Smith,

${ }^{36}$ Mickle's brother was a journeyman printer, associated with one of the conservative printers in Oxford, Daniel Price, and he was himself a proof-corrector for the Clarendon Press. A letter from his brother Charles conveys the precariousness of the family's circumstances: "I cannot bear the thoughts of your going abroad... I would have you tell them [his possible patrons] you shall come for some time to Oxford, and that they may put up a Ticket immediately. When you come my Sisters will make some Shirts; and as you will need a new suit of Cloaths, let Mr Grieg take your Measure before you leave Town, that if you again chuse Priest gray they may be sent here in a few weeks when it falls to its standard price." Letter from Charles Mickle to William Julius Mickle, dated November 9 [1765?], Osborn Mickle Papers, Beinecke Library.

${ }^{37}$ Smith, The Wealth of Nations, pp. 405, 610, 722-723.

38 "It is not the little cunning finesse of embroiling the Indian princes among themselves; of cajoling one, and winning another; it is not the groveling arts of intrigue, often embarrassed, always shifting, which can give lasting security." Mickle, "Introduction" (1778), p. clxxxvi.

${ }^{39}$ Mickle, "Introduction" (1778), p. clxxxvi.

${ }^{40}$ Smith, The Wealth of Nations, pp. 838, 934.

${ }^{41}$ Smith, The Wealth of Nations, p. 638.

${ }^{42}$ Smith, The Wealth of Nations, p. 471. 
43 William Bolts, Considerations on India Affairs; particularly respecting the present state of Bengal and its Dependencies, 3 vols. (London, 1772-1775), vol. 1, pp. vi-vii, 85. Smith owned a copy of Bolts's book, and his arguments about the East India Company follow Bolts fairly closely.

${ }^{44}$ The review in the August 1776 issue of the Gentleman's Magazine which praised Mickle's understanding of Indian commerce, and contrasted it to Smith's, was thus immediately preceded by the following three articles: "Qualifications of a Siberian hairdresser" (pp. 360-361), "Declaration of American Independency" (pp. 361-362), and "History of the Decline and Fall of the Roman Empire” (pp. 365-367). Gentleman's Magazine, vol. 46 (August 1776).

${ }^{45}$ Mickle, A Candid Examination, p. 18.

${ }^{46}$ Mickle, "Introduction" (1778), p. ccxxv.

${ }^{47}$ Letters of January 101776 and April 3 1776, from Robert Walpole in Lisbon, and letter of February 131776 from Lord Weymouth in London to Robert Walpole, The National Archives, SP89/81, 16r-v, 41r, 199r-200v, 201r, 201v. 